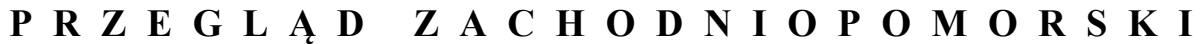 ROCZNIK XXXIII (LXII) ROK 2018 ZESZYT 1
}

\author{
RYSZARD TECHMAN \\ Archiwum Straży Granicznej \\ e-mail: rysz.tech@wp.pl

\section{Czechoseowacka żegluga na Odrze w latach 1947-1957 Część I}

Słowa kluczowe: żegluga czechosłowacka, żegluga odrzańska, żegluga śródlądowa, Czechosłowacja, Odra

Keywords: Czechoslovak navigation, Oder navigation, river navigation, Czechoslovakia (the Czechoslovak Republic), the Oder

Handel zagraniczny Czechosłowacji, która nie dysponowała bezpośrednim dostępem do morza, korzystał w międzywojniu m.in. ze śródlądowych dróg wodnych - Łaby, Dunaju i Odry, umożliwiających dotarcie do portów leżących nad morzami: Północnym, Czarnym i Bałtyckim. Rząd w Pradze wkrótce po uzyskaniu niepodległości w 1918 roku zainteresował się szlakiem odrzańskim i Szczecinem, położonym korzystniej w stosunku do przemysłowego zaplecza Republiki Czechosłowackiej niż niemiecki Hamburg, włoski Triest czy Gdańsk i Gdynia. Zwrócenie się ku Bałtykowi gwarantował traktat wersalski, który dawał temu państwu prawo wydzierżawienia terenu wolnocłowego w porcie szczecińskim oraz przyznawał z niemieckich zasobów tabor rzeczny. Stanowił on podstawę powołania z początkiem 1924 roku Czechosłowackiego Towarzystwa Akcyjnego Żegluga na Odrze (Československá plavební akcíová společnost oderská ČSPSO) w Ostrawie z udziałem kapitału państwowego oraz zakładów Vítkovice, później firmy Bata, a od 1935 roku również Czechosłowackiego Towarzystwa Akcyjnego Żegluga na Łabie. Armator ostrawski, tworzący spółkę eksploatacyjną 
ze szczecińską Ostreederei, zajmował się transportem ładunków (zwłaszcza rudy oraz węgla) przede wszystkim Odrą, ale też niemieckimi kanałami do Łaby i tą rzeką, przewożąc w swym najlepszym okresie do $0,5 \mathrm{mln}$ ton towarów rocznie. Przeszkodą w jego rozwoju były m.in. wysokie stawki w portach odrzańskich oraz trudności nawigacyjne, najczęściej związane z niskimi stanami wód ${ }^{1}$.

Czechosłowacki tabor rzeczny na Dunaju, Łabie i Odrze liczył w 1937 roku 546 jednostek pływających (barki i holowniki) o pojemności 249278 ton i mocy $39802 \mathrm{KM}$. W relacjach z zagranicą przetransportował wtedy 3601380 ton, co stanowiło 15,8\% ogółu towarów, których 84,2\% (19 153560 t) obsłużyła kolej. $\mathrm{Z}$ trzech największych armatorów, ČSPSO było najsłabszym ogniwem czechosłowackiej żeglugi śródlądowej, dysponując w tym okresie 90 barkami o łącznym tonażu 34600 ton, niemniej dla wykonania ówczesnych zadań dodatkowo dzierżawiło znaczną liczbę jednostek ${ }^{2}$. W ciągu ostatnich kilku lat przed drugą wojną światową dyskryminacyjne poczynania Niemiec spowodowały, że barki i holowniki tego towarzystwa stopniowo przechodziły na Łabę, zgodnie z ważnym kierunkiem ekspansji handlu zagranicznego ČSR, korzystającej najczęściej z portu hamburskiego.

\section{Funkcja transportowa Odry w polsko-czechosłowackich stosunkach po zakończeniu drugiej wojny światowej}

Upadek III Rzeszy po przegranej wojnie i dominacja sowiecka w Europie Środkowo-Wschodniej przyniosły zasadnicze zmiany polityczno-gospodarczej sytuacji Polski i Czechosłowacji, które znalazły się w obszarze wpływów Moskwy. W wyniku przesunięć terytorialnych, część dotychczasowych ziem niemieckich, szlak odrzański na zdecydowanej długości swego biegu oraz wyjście na Bałtyk znalazły się po stronie polskiej. Z tego choćby względu sprawy komunikacyjne nabrały niemałej wagi w interesach obu państw, charakteryzujących się znaczną współzależnością tranzytową. Władze w Warszawie, świadome zainteresowania

1 Národní archiv Česke republiky Praha (dalej NA Praha), Ministerstvo Dopravy II (dalej MD II), karton (dalej kr.) 685: „Zpráva o československé plavbě na Odře”, 1955; Slovník veřejného pravá československého, t. 2, red. J. Havelka, Brno 1932, s. 1088; B. Švarc, Czechosłowacka żegluga śródlądowa na obszarze Europy Środkowej, „Technika i Gospodarka Morska” (dalej TGM) 1974, nr 12, s. 745; B. Dopierała, Powiazania Szczecina z Czechosłowacja w dwudziestoleciu międzywojennym, „Przegląd Zachodni” 1961, nr 2, s. 307-311; tenże, Zarys dziejów Odry, w: Odra i Nadodrze, Warszawa 1976, s. 52-54; K. Beister, Geneza czechosłowackiej strefy wolnoctowej w Szczecinie, „Przegląd Komunikacyjny” 1949, nr 6, s. 176-178.

2 NA Praha, MD I, k. 810, „Reorganisace státní spravy plavební” 1949. 
Pragi gospodarką morską, podjęły wkrótce po zakończeniu wojny starania, by wykorzystać potencjalne korzyści tkwiące w usytuowaniu Odry i portu szczecińskiego wobec naddunajskiego zaplecza ${ }^{3}$. Sprawa stała się dla nich elementem karty przetargowej w trwającym konflikcie granicznym o Zaolzie oraz Ziemię Kłodzką, Raciborską i Głubczycką. Dał to do zrozumienia po powrocie z Poczdamu minister spraw zagranicznych RP Wincenty Rzymowski, twierdząc, iż „jeśli Czesi chcą mieć udział w żegludze na Odrze i porcie Szczecina, to muszą przyjść do nas, do Warszawy. A załatwienie tych spraw uzależnimy od załatwienia sprawy Zaolzia"4. To credo polskiej dyplomacji, warunkujące uregulowanie całokształtu stosunków od obustronnych koncesji - czechosłowackiego zrzeczenia się pretensji granicznych oraz rozwiązania innych problemów politycznych w zamian za szeroko idące przywileje gospodarcze i ustępstwa ze strony Polski (nie tylko portowo-żeglugowe), obowiązywało przez wiele następnych miesięcy5. W podobnym właściwie tonie wypowiadali się niektórzy przedstawiciele prywatnych sfer gospodarczych, a realizacja ich koncepcji miała zapewnić Czechosłowacji nieskrępowany i własny dostęp do morza, Polsce natomiast przypływ towarów tranzytowych do portów bałtyckich, pozwalający na konkurowanie z Hamburgiem ${ }^{6}$. Eksperci w Pradze z początku sceptycznie patrzyli na możliwości tranzytu morskiego przez Polskę i bliższe związanie się ze Szczecinem, co wynikało również z niepewnej sytuacji politycznej miasta, radzieckiej w nim obecności i zniszczeń tutejszego portu?

Brak poprawnych stosunków politycznych między Warszawą i Pragą na tle sporu o granicę, negatywnie rzutował na podjęcie współpracy gospodarczej obu państw. Do zasadniczych rokowań doszło w Pradze w lutym i marcu 1946 roku,

3 R. Techman, Szczecin w aktach polskiej stużby dyplomatycznej 1945-1950, w: 50 lat Polski na Pomorzu Zachodnim. Polityka - Spoleczeństwo - Kultura. Materiały z sesji naukowej (1920 maja 1995), red. K. Kozłowski, E. Włodarczyk, Szczecin 1996, s. 65.

4 Archiwum Akt Nowych w Warszawie (dalej AAN Warszawa), Biuro Prezydialne Krajowej Rady Narodowej (dalej BP KRN), sygn. 69, s. 424-425; R. Techman, Szczecin w aktach..., s. 65-66.

5 M.K. Kamiński, Polsko-czechostowackie stosunki polityczne 1945-1948, Warszawa 1990, s. 347.

6 A. Hutnikiewicz, Szczecin w stosunkach polsko-czechostowackich 1945-1950, w: Historia luxveritatis. Księga pamiątkowa dedykowana profesorowi Zdzisławowi Chmielewskiemu z okazji 60 rocznicy urodzin, Szczecin 2002, s. 372.

7 Archiv Ministerstva zahraničních věcí Praha (dalej AMZV Praha), Zaztupitelsky Úřad (dalej ZÚ) Varšava 1945-1955, kr. 110: raporty posła J. Hejreta z 12.09. i 25.11.1945 do MZV; kr. 128: raporty posła J. Hejreta do MZV z 25.05. i 13.08.1945. 
kiedy Czechosłowacja wysunęła m.in. wiele postulatów dotyczących komunikacji, których realizacja dawałaby temu państwo dostęp do morza ${ }^{8}$.

W trakcie rokowań rozważane były między innymi kwestie zmiany obowiązującej przed wojną konwencji handlowej i nawigacyjnej między II Rzeczpospolitą a Czechosłowacją, podpisanej 10 lutego 1934 roku, a przede wszystkim korzystania ze śródlądowych dróg wodnych, na znaczenie których Praga kładła szczególny nacisk. Stronie polskiej przedstawiono 12 marca 1946 roku: „Postulaty czechosłowackie w dziedzinie żeglugi morskiej, śródlądowej i tranzytu oraz związanych z tym zagadnień", które wskazywały m.in. na konieczność zapewnienia wolności żeglugi i tranzytu na rzekach obu państw, przewozów zwolnionych od opłat i ceł, uznawania klauzul celnych, swobodnego tworzenia agencji, biur transportowych, wzajemnego popierania warunków komunikacyjnych i tranzytowych; zagwarantowania wolnej strefy w porcie szczecińskim (na 99 lat), wspólnej budowy kanału Odra-Dunaj'.

Zagadnienia żeglugi morskiej byłyby objęte przyszłym traktatem handlowym i nawigacyjnym, natomiast propozycja czechosłowacka dotyczyła konieczności przygotowania nowej umowy o żegludze śródlądowej oraz wyodrębnienia w specjalnych układach spraw szczecińskiej strefy wolnej i kanału Odra-Dunaj. Priorytetem miało być jednak szybkie rozpoczęcie własnej żeglugi na Odrze, przy czym Czechosłowacy odwoływali się do wcześniejszego funkcjonowania na tej rzece przedsiębiorstwa armatorskiego, którego część taboru ocalała, wskazując również na potrzebę użytkowania niemieckich dróg śródlądowych przez Mittellandkanal ${ }^{10}$.

Warszawa, trzymając się zasady, że może udzielić Pradze zdecydowanie dalej idących koncesji niż innym krajom, ale po uregulowaniu stosunków, uchylała się od rozmów na temat żeglugi odrzańskiej. Nie odżegnywała się jednak od bilateralnej współpracy na Odrze, co miałoby zastąpić zobowiązania wielostronne,

8 M.K. Kamiński, Polsko-czechosłowackie stosunki..., s. 194-195; A. Hutnikiewicz, Szczecin w polskiej polityce morskiej w latach 1945-1950, Szczecin 1991, s. 174-176; L. Kulíková, Československo-polské hospodářské styky předuzavřenim spojenecké smlouvy (květen 1945-březen 1947), „Slovanské Historické Studie” 1992, t. XVIII, s. 228; T. Marczak, Granica zachodnia w polskiej polityce zagranicznej w latach 1944-1950, Wrocław 1995, s. 502.

9 AAN Warszawa, Ministerstwo Skarbu (dalej MS) II, sygn. 679: „Postulaty czechosłowackie w dziedzinie żeglugi morskiej, śródlądowej i tranzytu oraz związanych z tym zagadnień”, przesłane przy piśmie MŻiHZ z 1 IV 1946; tamże, Ministerstwo Komunikacji (dalej MK), sygn. 956, s. $81-85,181$.

${ }^{10}$ AAN Warszawa, MS II, sygn. 679: Notatka W. Jastrzębowskiego z 14.03.1946 „Sprawy żeglugowe w polsko-czechosłowackich rozmowach gospodarczych". 
uważając, że umożliwi to podważenie planów umiędzynarodowienia tej rzeki, niekorzystnych w obliczu przewidywanego zagrożenia ze strony Niemiec ${ }^{11}$. Ostatecznie rokowania lutowo-marcowe 1946 roku nie przyniosły rozstrzygnięć, niemniej dawały dobre podstawy pod dalsze polityczne i gospodarcze rozmowy ${ }^{12}$.

Na początku 1947 roku nastąpiło wyraźne zbliżenie w stosunkach polsko-czechosłowackich, co przypieczętował Układ o przyjaźni i wzajemnej pomocy, zawarty w Warszawie 10 marca tego roku. Stwierdzono w nim zgodność celów politycznych obu państw oraz ich dążenie do wspólnej obrony przed niemieckim odwetem, zapowiadano pogłębienie współpracy kulturalnej i gospodarczej na podstawie specjalnych umów. Rząd polski zrewidował swój niechętny stosunek do nawiązania ścisłych kontaktów ekonomicznych z Czechosłowacją ${ }^{13}$. Siłą rzeczy nowa sytuacja przełamała impas w rozmowach na temat wykorzystania Odry i Szczecina, z obustronnym pożytkiem, gdyż zbyt długie opóźnianie koncesji morskich dla południowego sąsiada Rzeczypospolitej, wyzwalało naturalne tendencje do rozbudowy interesów tego kraju dzięki innym portom, zwłaszcza niemieckim ${ }^{14}$.

W kwietniu 1947 roku zainaugurowano w Pradze polsko-czechosłowackie rokowania gospodarcze, które obejmowały wiele umów dotyczących handlu, transportu, przemysłu, rolnictwa i leśnictwa, dostaw inwestycyjnych. W interesujących nas kwestiach rozbieżności poglądów odnosiły się przede wszystkim do formy prawnej przyszłego przedsiębiorstwa żeglugowego na Odrze oraz rejonu wolnocłowego w Szczecinie, systemu refakcji taryfowych. Praskie władze uważały, że kanałowe wydłużenie żeglowności Odry z Koźla do Ostrawy przyniesie im, z punktu widzenia prawa międzynarodowego, pozycję równą z Polską, godząc odmienne koncepcje w sprawie statusu tej rzeki ${ }^{15}$.

${ }^{11}$ Liczono na wycofanie się Czechosłowacji z popierania brytyjskiego projektu umiędzynarodowienia tej rzeki, A. Hutnikiewicz, Szczecin w stosunkach..., s. 374-375.

${ }^{12}$ AAN Warszawa, MS II, sygn. 679: Notatka W. Jastrzębowskiego z 14.03.1946 „Sprawy...”; J. Skodlarski, Rokowania gospodarcze polsko-czechostowackie w 1947 r., w: „Acta Oeconomica Pragensia" 2007, nr 7, s. 352.

${ }^{13}$ M.K. Kamiński, Polsko-czechostowackie stosunki..., s. 311-312, 347; K. Kořalková, Československo-polské vztahy 1945-1961, Praha 1962, s. 22-26; Z. Opoka, Stosunki polsko-czechostowackie w latach 1944-1948, Zeszyty Naukowe Wojskowej Akademii Politycznej 1973, nr 75, s. 156-157.

${ }^{14}$ R. Techman, Szczecin waktach..., s. 66.

${ }^{15}$ NA Praha, Úřad předsednictva vlády (dalej ÚPV)-B (běžná spisovna), kr. 1142: pismo ÚPV do MD z 24.06.1947 w sprawie rokowań o czechosłowackiej żegludze na Odrze. 


\section{Prawno-organizacyjne i kadrowe warunki dzialalności czechosłowackiego armatora na Odrze.}

\section{Powołanie i organizacja czechosłowackiego przedsiębiorstwa żeglugowego}

Wynikiem polsko-czechosłowackich rokowań gospodarczych była Konwencja o zapewnieniu współpracy gospodarczej między Polską a Czechosłowacją, podpisana w Pradze 4 lipca 1947 roku. Zawarty w jej ramach Układ Komunikacyjny (załącznik 6) zapewniał ČSR m.in. szerokie uprawnienia w porcie szczecińskim w postaci wolnego obszaru celnego (późniejszego rejonu przeładunkowego) ${ }^{16}$, uprzywilejowaną pozycję dla planowanej żeglugi rzecznej i morskiej, umożliwiając temu państwu korzystanie z portów wybrzeża Rzeczypospolitej jako baz żeglugowo-technicznych dla statków handlowych na warunkach stosowanych wobec polskich jednostek pływających ${ }^{17}$.

Zagadnienia żeglugi śródlądowej i portów rzecznych ujęto w przepisach rozdziału E, którego rozwinięciem i uzupełnieniem był osobny załącznik (6 b) - „Zasady wspótpracy Polsko-Czechostowackiej na Odrze”18. Rząd w Pradze został uprawniony do tworzenia spółki żeglugowej z siedzibą w Polsce, funkcjonującej w ramach polskiego ustawodawstwa, w dowolnej formie prawnej, której statut lub umowa byłyby zatwierdzane przez władze RP, podobnie jak udzielenie 30-letniej koncesji na przewozy towarowe. Przed rozpoczęciem działalności obcą spółkę zobowiązano do zawarcia umowy o współpracy z polskimi armatorami na Odrze w sprawach wykorzystania taboru pływającego, zasad i sposobu rozrachunków za transport towarów, stosowania taryf przewozowych i przeładunkowych, zatrudniania obywateli polskich. Ponadto oba państwa (rozdział F) zgodziły się przeprowadzić niezbędne prace wstępne i przystąpić do budowy kanału odrzańsko-dunajskiego. Zagadnieniami organizacyjnymi, technicznymi i gospodarczymi zajmować się miał Polsko-Czechosłowacki Komitet Studiów dla Spraw

\footnotetext{
${ }^{16}$ Zob. szerzej A. Szczepańska, Rejon czechosłowacki w porcie szczecińskim w latach 1949 1956, „Przegląd Zachodniopomorski” 2006, nr 3, s. 49 i n.

${ }^{17}$ J. Skodlarski, Procesy integracyjne w polsko-czechostowackich stosunkach gospodarczych (1947-1949), „Acta Universitatis Lodziensis”, Nauki Ekonomiczne i Socjologiczne 1979, seria III, nr 39, s. 25 i n, 50 i n; A. Hutnikiewicz, Szczecin w polskiej..., s. 181-187; T. Bissaga, Komunikacje w konwencji polsko-czechostowackiej, „Życie Gospodarcze” 1948, nr 6, s. 244-246; J. Zintel, Układ komunikacyjny polsko-czechostowacki, „Gospodarka Morska” 1948, nr 1, s. 68-72.

18 Archiwum Państwowe w Szczecinie (dalej APS), Szczeciński Urząd Morski (dalej SUM), sygn. I/100: „Zasady współpracy polsko-czechosłowackiej na Odrze” zał. nr 6b Układu Komunikacyjnego z 4.07.1947; T. Bissaga, Komunikacje w konwencji..., s. 246.
} 
Drogi Wodnej Odra-Dunaj, będący organem Polsko-Czechosłowackiej Komisji Komunikacyjnej ${ }^{19}$.

W dniach 7 i 8 października 1947 roku odbyły się we Wrocławiu wstępne rozmowy między przedstawicielami przedsiębiorstw żeglugi śródlądowej - Polską Żeglugą na Odrze (PŻnO) sp. z o.o. oraz (reaktywowanym) Czechosłowackim Żeglugowym Towarzystwem Akcyjnym na Odrze (ČPASO) w Ostrawie. Czechosłowacy zadeklarowali zorganizowanie w najbliższym czasie delegatury we Wrocławiu oraz wprowadzenie na Odrę do końca marca 1948 roku barek o tonażu 30 tys. t. Dokładniejsze ustalenia co do spraw organizacyjnych, eksploatacyjnych oraz technicznych planowanej do utworzenia nowej spółki miały zapaść na wspólnych konferencjach w Ostrawie (listopad 1947) i Wrocławiu (styczeń 1948). Byłyby one również podstawą do zawarcia umowy o współpracy między czechosłowackim a polskim przedsiębiorstwem ${ }^{20}$.

Zgodnie z wcześniejszymi zapowiedziami, 14 listopada 1947 roku przybyło do Wrocławia kilku urzędników ČPASO, tworząc jego przedstawicielstwo, zlokalizowane w budynku PŻnO przy ul. Klęczkowskiej 48. Otrzymali oni zadanie przygotowania zrębów organizacyjnych i finansowo-administracyjnych przyszłej spółki prawa polskiego, warunków do współdziałania z polską stroną i werbunku miejscowego personelu. Czechosłowacy przyjęli wstępnie, że nowy twór będzie samodzielny (czego domagała się Warszawa), a jednocześnie jak najściślej powiązany z macierzystą jednostką w Ostrawie. Takie rozwiązanie miało gwarantować pełną kontrolę i właściwe kierowanie oraz skutkować ograniczeniem wydatków rzeczowych i personalnych, gdyż ogólne kierownictwo żeglugi na Odrze pozostawałoby w rękach dyrektorów ČPASO (Frantíšek Fára i Vojtěch Sobotík). Na stałe we Wrocławiu pozostał Robert Marek, prokurent ostrawskiego towarzystwa ${ }^{21}$.

Strona czechosłowacka nalegała na szybkie zakończenie rozmów, by można było rozpocząć eksploatację na Odrze z początkiem sezonu nawigacyjnego 1948 roku. Chodziło zwłaszcza o sfinalizowanie spraw formalno-prawnych

\footnotetext{
${ }^{19}$ APS, SUM, sygn. I/100: „Zasady współpracy ...”.

${ }^{20}$ AAN Warszawa, Centralny Urząd Planowania (dalej CUP), sygn. 1871, s. 42-43, 45, Komunikat z konferencji w dniach 7 i 8 października br. we Wrocławiu pomiędzy ČPASO w Ostrawie a Polską Żeglugą na Odrze; pismo PŻnO we Wrocławiu z 18.11.1947 do Ministerstwa Komunikacji.

${ }^{21}$ NA Praha, ÚPV-B, kr. 958: odpis bezúročných státních zápůjček u národních dopravních podniků ČSPLO, ČSPO a ČSPD; AAN Warszawa, CUP, sygn. 1871, s. 42-44: pismo ČPASO z 4.11.1947 do PŻnO; pismo PŻnO we Wrocławiu z 18.11.1947 do MK; tamże, Ministerstwo Żeglugi (dalej MŻ), sygn. 121, s. 34-40: „Obsługa tranzytu przez żeglugę śródlądową i stan przygotowania portów rzecznych" - 24.10.1956.
} 
związanych z założeniem i zarejestrowaniem wrocławskiej firmy, utworzenie kilku agentur w terenie, uzyskanie koncesji na prowadzenie działalności, rozwiązanie zagadnień taryfowych, techniczno-nawigacyjnych, zalegalizowanie dokumentów jednostek pływających, wreszcie zawarcie stosownej umowy z polskim przedsiębiorstwem ${ }^{22}$. Wypracowanie zasad prawno-organizacyjnej i gospodarczej obecności Czechosłowacji na odrzańskim szlaku komunikacyjnym trwało jednak kilka miesięcy, podczas których doszło do licznych konferencji, konsultacji i spotkań stron w celu uzgodnienia stanowisk ${ }^{23}$.

12 maja 1948 roku podpisano we Wrocławiu umowę spółki z ograniczoną odpowiedzialnością Czechosłowacka Żegluga na Odrze (Československá plavba na Odře společnost z rucenim obmezenym), która oficjalnie miała używać skrótu ČSPO ${ }^{24}$. Powołano ją do przewozu towarów na Odrze wraz z jej dopływami i łączącymi się z nią kanałami; prowadzenia stoczni oraz pomocniczych warsztatów dla naprawy własnego taboru pływającego. Czas funkcjonowania spółki ustalono na okres obowiązywania koncesji i termin jej ewentualnego przedłużenia. Kapitał zakładowy wynosił $1 \mathrm{mln}$ zł, i był podzielony na 100 udziałów po 10 tys. zł, przy czym każdy ze wspólników, a więc rząd czechosłowacki oraz ČPASO miał po 50 udziałów. Władze Czechosłowackiej Żeglugi na Odrze stanowiły: zgromadzenie wspólników, radę nadzorczą i zarząd. Przewodniczącego i jednego członka Rady Nadzorczej ČSPO wyznaczał rząd czechosłowacki (minister komunikacji); kolejnego członka i zastępcę przewodniczącego wskazywała Ostrawa. Identyczną liczbę osób, trwanie ich mandatu (trzy lata) oraz zasadę podziału uwzględniono przy wyborze zarządu ČSPO ${ }^{25}$. Skład personalny kolegium

${ }^{22}$ Archiwum Ministerstwa Spraw Zagranicznych w Warszawie (dalej AMSZ Warszawa), Zespół (dalej Z) 28, wiązka (dalej w.) 13, t. 80, s. 1-3: pisma ČPASO z 22 i 23.12.1947, pismo PŻnO z 24.12.1947.

${ }^{23}$ AAN Warszawa, MK, sygn. 956, s. 45-46, s. 69: spr. z konf. w Ostrawie 21-23.01.1948; tamże, Ministerstwo Handlu Zagranicznego (dalej MHZ), sygn. 92/27: prot. z I posiedz. Czech.-Pol. Kom. Komunik. w dniach 5-10.03.1948 w Pradze; tamże, Ministerstwo Przemysłu i Handlu (dalej MPiH), sygn. 3563, s. 6-8: not. z konf. 5 i 6.04 .1948 we Wrocławiu; AMSZ Warszawa, Z. 28, w. 13, t. 80 , s. 6 : pismo MK z 21.04.1948.

${ }^{24}$ Akt notarialny podpisali: dr praw Antonín Habenicht (radca, szef prez. Min. Komun., reprez. rząd ČSR) oraz dr nauk techn. Jan Tille (zast. nacz. dyr. przed. państw. „Báňská a hutní společnost, Narodni Podnik") - w imieniu firmy ČPASO.

${ }^{25}$ AAN Warszawa, MK, sygn. 955, s. 3-5, 17-26: akt notarialny z 12.05.1948. Spółka została wpisana do rejestru Sądu Okręgowego (Wydział I Cywilny) we Wrocławiu w dziale B nr 129 [I RHB/II-129] 14.09.1948. 
i zarządu gwarantował pełną kontrolę decydentów ČSR nad funkcjonowaniem przewoźnika w Polsce ${ }^{26}$.

Akt notarialny spółki wrocławskiej był pierwszym krokiem do formalno-prawnego zatwierdzenia jej działalności w Polsce, do czego doszło kilka tygodni wcześniej. Nadal natomiast trwały uzgodnienia międzyresortowe w sprawie koncesji oraz warunków współpracy z polskim armatorem na Odrze, a także opodatkowania ČSPO w Rzeczypospolitej wobec rozbieżnych opinii ministerstw spraw zagranicznych oraz skarbu ${ }^{27}$. Ponadto ambasada ČSR w Warszawie zwróciła się notami z 13 kwietnia oraz 11 maja 1948 roku do polskiego MSZ z prośbą o jak najszybsze zwołanie konferencji, na której uzgodniono by ostateczne warunki importu i eksportu towarów transportowanych Odrą, celnej odprawy statków, ładunków oraz osób przy przekraczaniu granicy ${ }^{28}$.

Uchwałą Rady Ministrów z 26 sierpnia 1948 roku polski minister komunikacji został upoważniony do zatwierdzenia w imieniu rządu RP umowy spółki z o.o. Czechosłowacka Żegluga na Odrze oraz udzielenia jej zezwolenia na uprawianie żeglugi śródlądowej. Na tej podstawie szef tego resortu wydał ČSPO 23 października tego roku dokument koncesyjny ${ }^{29}$, w którym powtarzano właściwie główne ustalenia zawarte w majowej umowie spółki co do m.in. zakresu jej działania, wielkości taboru na Odrze, okresu trwania. Strona polska gwarantowała również uznanie czechosłowackich dokumentów dla floty odrzańskiej oraz przeglądów technicznych jednostek pływających, a także świadectw i patentów żeglarskich wydanych przez właściwe urzędy południowego sąsiada Polski. Czechosłowacy byli uprawnieni do wydzierżawiania potrzebnych terenów w portach odrzańskich

${ }^{26}$ Rząd ČSR wyznaczył już w kwietniu 1948 r. przedstawicieli do CSPO - do Zarządu weszli: Antonín Habenicht (przewod.) oraz inż. Ládislav Vavrouch (radca Min. Techniki), jako członek, natomiast do Rady Nadzorczej: jej przewod. dr praw Cyril Černý (nacz. w Min. Komun.) i członek Oldřich Dostál (gł. ks. Min. Skarbu). Z kolei ČPASO 16.04.1948 r. wyznaczyła na członków i jednocześnie zastępców przewod. CSPO: Zarządu Jana Tille, a Rady Nadzorczej - dr. praw Františka Klauda - NA Praha, ÚPV-B, k. 958: odpis bezúročných státních zápůjček u národních dopravních podniků ČSPLO, ČSPO a ČSPD; AAN, MK, sygn. 955, s. 8, 10, 15.

${ }^{27}$ AAN Warszawa, MK, sygn. 954: prot. z konf. z 25.06.1948, pismo MK z 2.07.1948 do MŻ, pismo MSZ z 4.09.1948 do MS; APS, SUM, sygn. I/107: sprawozdanie Sekcji Polskiej Komitetu Rzecznego (09.1948).

${ }^{28}$ AMSZ Warszawa, Z. 28, w. 13, t. 80: tłum. not nr 3623/48 z 13.04.1948 i 4702 z 11.05.1948.

29 AAN Warszawa, Ministerstwo Ziem Odzyskanych (dalej MZO), sygn. 1385 a, s. 52-64; tamże, MŻ, sygn. 1538; Archiwum Państwowe we Wrocławiu (dalej AP Wrocław), Zjednoczenie Żeglugi Śródlądowej (dalej ZŻS), sygn. 2/529, s. 66-73; Archiwum Państwowe w Gdańsku, Oddział w Gdyni (dalej AP Gdynia), Urząd Celny w Gdyni (dalej UC), sygn. 186, s. 68-73. 
i w Szczecinie, jak również odpowiednich urządzeń dla przeładunku i składowania ładunków oraz stoczni. Mieli również możliwość utrzymywania własnych przedstawicielstw czy agencji i warsztatów remontowych. Koncesjonariusz samodzielnie ustalał warunki i wysokość kosztów przeładunku i przewozu swoim taborem towarów przeznaczonych dla ČSR lub pochodzących z tego kraju, a przewożonych tranzytem przez Polskę. Mógł przy zachowaniu prawnej i gospodarczej odrębności zawierać umowy o współpracę z polskimi armatorami na Odrze, ale bez ich zgody nie miał prawa czynić tego w odniesieniu do przedsiębiorstw innych państw. Otrzymał zgodę na zatrudnienie obywateli polskich oraz swobodę w ustalaniu wynagrodzeń za pracę swoich rodaków, niezależnie od płac w Rzeczypospolitej. Musiał z kolei opłacać od wpływów za przewóz towarów polskich lub przeznaczonych dla Polski obowiązujące podatki, z innych został właściwie zwolniony specjalnie ustanowionym dlań przywilejem, co odnosiło się również do tzw. tono-kilometrowych opłat za korzystanie z dróg wodnych.

Jednym z warunków funkcjonowania czechosłowackiego armatora na Odrze, które zawierały postanowienia Układu Komunikacyjnego oraz umowa spółki i dokument koncesyjny, było zawarcie z polskim przewoźnikiem odrzańskim stosownego porozumienia o współpracy. Z mniejszym lub większym natężeniem prace nad finalizacją tego aktu prawnego trwały niemal rok. Różnice, które dzieliły przewoźników, dotyczyły przede wszystkim kwestii eksploatacyjnych, a zwłaszcza tzw. regulaminu przewozowego na Odrze ${ }^{30}$.

Dopiero 26 listopada 1948 roku, po kilkumiesięcznym okresie eksploatacji drogi odrzańskiej przez południowego sąsiada Polski, została podpisana we Wrocławiu „Ramowa umowa o współpracę” między Państwową Żeglugą na Odrze i Czechosłowacką Żeglugą na Odrze, spółka z o.o. W umowie zakładano jak najdalej idące wykorzystanie taboru pływającego obu stron, ustalanie taryf przewozowych i przeładunkowych, warunków pracy oraz wysokości wynagradzania, zakresu i zasad zatrudniania przez CSPO obywateli polskich, wzajemną pomoc i współdziałanie w działalności techniczno-przewozowej. Obaj przewoźnicy zobowiązywali się do prowadzenia wspólnej polityki żeglugowej¹.

Poza Wrocławiem, gdzie mieściły się siedziby dyrekcji i placówki dyspozycyjnej, Czechosłowacy utworzyli również agendy terenowe. W końcu marca

${ }^{30}$ AAN Warszawa, MZO, sygn. 1385 a, s. 16-21: proj. czechosł. o współpracy pomiędzy Państwową Żeglugą na Odrze a Czechosłowacką Żeglugą na Odrze z 11.12.1947; tamże, MHZ, sygn. 92/27: „Sprawozdanie Sekcji Polskiej Komitetu Rzecznego” (09.1948).

${ }^{31}$ AAN Warszawa, MK, sygn. 954, sygn. 955: „Ramowa umowa o współpracę” z 26.11.1948. 
1948 roku powstała Delegatura CSPO w Szczecinie i, najpewniej w tym samym czasie, w Koźlu - obie prowadziły również stacje bunkrowe w tych portach oraz magazyny podręczne. Wspólne dla polskiej i obcej strony, dzielących się kosztami, były ekspozytury w Malczycach, Nowej Soli, Cigacicach, Kostrzyniu i Gryfinie. Te w Nowej Soli i Kostrzyniu prowadziły ponadto stacje bunkrowe dla obu armatorów, a w Krośnie Odrzańskim, Kostrzyniu i Gryfinie załatwiano również sprawy celne i graniczne ${ }^{32}$.

Powstanie odrębnego i prawnie samodzielnego przedsiębiorstwa żeglugowego we Wrocławiu, stanowiło dla macierzystej jednostki organizacyjnej w Ostrawie, która zapewniała nowej firmie tabor i kadry, niemały problem. Wrocławska CSPO miała problemy kadrowe, zwłaszcza dotyczące specjalistów: eksploatacyjno-żeglugowych, technicznych i finansowych, gdyż ČPASO nie kwapiła się z jego przerzuceniem do Polski, twierdząc, że pracownicy mają ważne zadania na terenie Czechosłowacji. Wprawdzie na czele spółki we Wrocławiu stał formalnie dyrektor z Ostrawy i jego zastępca, ale faktycznie nie urzędowali oni w stolicy Dolnego Śląska. Potrzeba kwalifikowanych i decyzyjnych sił na miejscu wymuszała konieczność szybkiego rozstrzygania zadań eksploatacyjnych, czego nie załatwiały instrukcje decydentów z Ostawy i ich doraźne przyjazdy do Wrocławia. Wzmocnienie personalne spółki wrocławskiej nastąpiło z początkiem nowej dekady (1950 r.), a funkcję kierowniczą na miejscu objął (po Robercie Marku) najpewniej Stanislav Jahn, dotychczasowy prokurent delegatury w Szczecinie ${ }^{33}$.

Nacjonalizacja przedsiębiorstw żeglugi śródlądowej w Czechosłowacji z początkiem 1949 roku spowodowała konieczność dokonania zmian w umowie ČSPO, które jednak nie miały większego znaczenia dla jej działalności. Upaństwowienie ČPASO i przejęcie jego masy majątkowej przez przedsiębiorstwo państwowe Czechosłowacka Żegluga na Odrze w Ostrawie (Československá plavbá oderská národní podnik - ČPO) nie wpłynęło na stosunek władz polskich do armatora we Wrocławiu „,z uwagi na konieczność utrzymania komunikacyjno-przewozowego ożywienia Odry, leżącego we wspólnym interesie obu zaprzyjaźnionych państw

\footnotetext{
${ }^{32}$ APS, Państwowa Żegluga na Odrze (dalej PŻnO), sygn. 38, s. 1-11: „Porozumienie szczegółowe na rok 1950 do ramowej współpracy pomiędzy Państwową Żeglugą Śródlądową a Czechosłowacką Żegluga na Odrze”, zawarte 9.03.1950 r. we Wrocławiu; ditto - NA Praha, MD I, kr. 298; M. Zawadka, Społeczne i gospodarcze aspekty wykorzystania Odry po II wojnie światowej, 1999, s. 129-130 - pr. dokt., mps, Bibl. Uniw. Zielonog.

${ }^{33}$ NA Praha, MD I, kr. 810: Zápis 15. (114) schůze správní rady Československé plavební akciové společnosti Oderské, konane dne 9 března 1949 v místnosti Báňské a hutní společnosti, národní podnik, Praha II".
} 
oraz w celu pogłębienia współpracy żeglugowej”. Na podstawie Uchwały Prezydium Rządu RP z 11 sierpnia 1950 roku, polskie Ministerstwo Komunikacji zatwierdziło zmianę wspólnika w umowie spółki z 12 maja 1948 roku $^{34}$.

Ważnym problemem dla funkcjonowania czechosłowackiego przedsiębiorstwa żeglugowego w Polsce była kwestia uregulowania wzajemnych relacji z ČPO w Ostrawie, do czego zmuszały względy organizacyjne, eksploatacyjne, finansowe czy personalne itd. W kręgach władz centralnych ČSR ścierały się z początku dwa poglądy. Pierwszy, uznający wrocławską spółkę za filię zakładu w Ostrawie, kłócił się jednak z faktem prawnej niezależności podmiotu w Polsce. Drugi z kolei respektował rzeczywistość, uznając istnienie samodzielnie prawnych i gospodarczych organizmów z siedzibami na ziemi różnych państw, z własną administracją, prowadzących odrębnie eksploatację ${ }^{35}$.

Wzajemne stosunki regulowały formalnie wytyczne Ministerstwa Komunikacji ČSR, które ten resort podpisał 14 stycznia 1950 roku, z mocą obowiązującą od początku poprzedniego roku. Ostatecznie ČPO i ČSPO miały tworzyć związek celowy, bez osobowości prawnej, którego zadaniem było zapewnienie jak najlepszego wykorzystania komunikacji wodnej na Odrze dla dobra czechosłowackiej gospodarki. Przedsiębiorstwo państwowe w Ostrawie stanowiło główny organ kierowniczy tego tworu, dyspozycyjny, kadrowy, finansowy, statystyczny, było więc centralą, natomiast spółka wrocławska zajmowałaby się bezpośrednio eksploatacją na Odrze. Wszelkie sprawy, które dotyczyły związku jako całości, miały być najpierw rozpatrywane w Ostrawie, a następnie przekazywane jako wniosek ČPO do załatwienia we Wrocławiu. Decyzje podejmowali przedstawiciele dyrekcji - ostrawska na terenie Czechosłowacji i wrocławska w Polsce. Utrzymano powiązania personalne między obu podmiotami - dyrektor z Ostrawy był w okresie pełnienia funkcji zarazem kierującym spółką wrocławską, odpowiadając za gospodarność i fachowe zarządzanie ${ }^{36}$.

\footnotetext{
${ }^{34}$ Sbírka zákonů Rep. Československé (Zbiór Ustaw Republiki Czechosłowackiej), ročnik 1948, část 108, zakon čís 311 ze dne 30.12.1948; NA Praha, ÚPV-B, kr. 1142: pismo MD z 1.10.1949 do MZV w Pradze; tamże, MD I, kr. 298: pismo MK RP z 13.09.1950; tamże, MD II, kr. 685: „Zpráva o československé plavbě na Odře”, 1955; AAN Warszawa, Urząd Rady Ministrów (dalej URM), sygn. 219/23: uchwała Prezydium Rządu z 11.08.1950 i jej uzasadnienie.

${ }^{35}$ NA Praha, ÚPV-B, kr. 958: odpis bezúročných státních zápůjček u národních dopravních podniků ČSPLO, ČSPO a ČSPD); tamże, MD I, k. 298: not. z narady 21.12.1949 w ČPO w Ostrawie; AAN Warszawa, MŻ, sygn. 121, s. 34-40: „Obsługa tranzytu przez żeglugę śródlądową i stan przygotowania portów rzecznych” - 24.10.1956.

${ }^{36}$ NA Praha, MD I, k. 298: „Směrnice k provedení bodu V. výnosu ministerstwa dopravy ze dne 26. ř́ína 1949”.
} 
Faktycznie ostrawski armator uważał spółkę wrocławską za swoją filię, całkowicie mu podporządkowaną. Nie widział konieczności, by ze względu na polskie urzędy, utrzymywać „fikcję ČSPO jako samodzielnej prawnie osoby fizycznej”. W rzeczywistości Wrocław był dlań tylko fasadą dla sterowania całością żeglugi w Polsce, jedynie wykonawcą eksploatacji, przy prowadzeniu polityki przez Ostrawę. Prawne uregulowanie stosunków nie mogło uszczuplić dotychczasowych prerogatyw, choćby ze względu na odpowiedzialność wobec organów nadrzędnych, a okoliczność, że faktycznie pełniła ona swe funkcje za pośrednictwem spółki wrocławskiej, niczego tu nie zmieniała. Z kolei Wrocław uważał ČPO i ČSPO za przedsiębiorstwa wspólne i równorzędne w żegludze śródlądowej na Odrze ${ }^{37}$.

Dokładnie w połowie 1952 roku doszło do kolejnej reorganizacji armatorów rzecznych w kraju nad Wełtawą: „Československá plavba labská” (ČPL) w Pradze i „Československá plavba oderská” (ČPO) w Ostrawie zostały połączone w jedno państwowe przedsiębiorstwo „Československá plavba labsko-oderská” (ČSPLO) z siedzibą w Pradze ${ }^{38}$. Praskie Ministerstwo Komunikacji uzasadniało fuzję utratą znaczenia ČPO wobec faktu, że to nie ona prowadziła działalność w Polsce, lecz za pośrednictwem oddzielnej spółki, do powstania której zmusiły władze polskie. Odmienna forma prawno-organizacyjna obu przedsiębiorstw rzekomo nie pozwalała Ostrawie rozwinąć funkcji organu kierującego i kontrolującego przewozy, tym bardziej, gdy przewagę zyskiwały sprawy ekonomiczne nad eksploatacyjno-technicznymi. Dzięki temu posunięciu miał powstać zwarty ośrodek-centrum m.in. do kierowania czechosłowacką żeglugą śródlądową na zapleczu portu szczecińskiego. Nowe przedsiębiorstwo stało się de facto właścicielem dotychczasowych udziałów ČPO w sp. z o.o. Czechosłowacka Żegluga na Odrze we Wrocławiu ${ }^{39}$.

Notą z 15 lipca 1952 roku ambasada ČSR w Warszawie powiadomiła polskie MSZ o reorganizacji swoich przewoźników rzecznych, stawiając ten resort przed faktem dokonanym, czego wcześniej nie praktykowano. W związku jednak z tym,

\footnotetext{
${ }^{37}$ Tamże, ÚPV-B, k. 958: odpis bezúročných státních zápůjček u národních dopravních podniků ČSPL, ČSPO, a ČSPD; tamże, MD I, kr. 298: pismo ČPO z 19.05.1950 do MD; kr. 821: pismo spółki z o.o. CSPO we Wrocławiu z 27.07.1950 do MS RP w sprawie zwolnienia od podatku obrotowego; AAN Warszawa, MK, sygn. 955, s. 14: pismo MK z 6.04.1950 do MSZ RP.

38 „Sbírka zákonů republiky Československe” 1952, nr 25, s. 185; NA Praha, MD I, kr. 225: „Vládní nařízení ze dne 1. července 1952”; B. Švarc, Czechosłowacka żegluga..., s. 746.

${ }^{39}$ NA Praha, MD I, kr. 225: pismo MD z 12.06.1952 do ÚPV w sprawie projektu zarządzenia o połączeniu państw. przed. transp., „Vladní nařízení o sloučení ČSPL a ČSPO” z 30.06.1952.
} 
że zmiana udziałowca w spółce z o.o. „Czechosłowacka Żegluga na Odrze” we Wrocławiu nie miała wpływu na jej status prawny i w dalszym ciągu pozostawała ona w ramach ustawodawstwa PRL, Warszawa nie interweniowała w tej sprawie, poprzestając na zwołaniu konferencji z udziałem zainteresowanych stron. Wobec braku danych, co do struktury nowo powstałego przedsiębiorstwa w Pradze, jej uczestnicy nie byli w stanie stwierdzić, w jaki sposób połączenie armatorów na Łabie i Odrze wpłynie na działalność żeglugową spółki wrocławskiej. Przypuszczano słusznie, że strona czechosłowacka dąży do stworzenia wspólnego taboru na obu rzekach, co umożliwiłoby jej większą swobodę ruchów ${ }^{40}$.

Formalnie w drugiej połowie 1952 roku nadal funkcjonowała w Polsce. Czechosłowacka Żegluga na Odrze sp. z o.o., jakkolwiek w końcu poprzedniego roku jej centrala została przeniesiona z Wrocławia do Koźla, gdzie powstało centrum dyspozycyjno-eksploatacyjne dla trasy odrzańskiej. Dokonano także zwrotu w strukturze ČSPLO - Koźle wraz z terenowymi agendami stanowiło teraz tzw. zakład Odra (závod Odra) tego przedsiębiorstwa z dyrektorem na czele, które to stanowisko pełnili kolejno: Josef Arabaš, František Laríš i Alois Oprchalski. W połowie lat pięćdziesiątych XX wieku kozielska placówka obejmowała organizacyjnie oddziały: Rachunkowości, Planowania, Przewozowy (Transportowy), Techniczny, Eksploatacyjny (Ruchu), Pracy i Płac, Buchalterii Płac oraz Referat dla Warsztatów i Łodzi ${ }^{41}$.

Poza Koźlem Czechosłowacy mieli w tym okresie agencje we Wrocławiu (jej kierownik sprawował jednocześnie funkcję kontaktowego urzędnika z polską żeglugą) i w Szczecinie oraz Inspektorat w Widuchowej. Obie agencje były obsadzone inspektorami transportowymi, którzy oprócz lokalnego kierowania przewozami prowadzili i kontrolowali funkcjonowanie załóg i stany techniczne taboru pływającego, przesyłając kozielskiej dyrekcji regularne komunikaty. W Koźlu i Szczecinie znajdowały się również warsztaty remontowe, magazyny

${ }^{40}$ AAN Warszawa, URM, sygn. 2/332: „Notatka w sprawie połączenia Czechosłowackiej Żeglugi na Odrze z siedzibą w Ostrawie z Czechosłowacką Żeglugą na Łabie z siedzibą w Pradze w jedno przedsiębiorstwo państwowe „Czechosłowacka Żegluga na Łabie i Odrze” z siedzibą w Pradze" - 12.11.1952.

${ }^{41}$ NA Praha, ÚPV-T(tajná spisovna), kr. 1286: „Zpráva o výsledku revise československé plavby na Odře" - 30.07.1955; tamże, MD I, kr. 821: pismo CSPO z 7.12.1951 do MD i uwagi o pertraktacjach czech.-pol. 
zaopatrzenia techniczno-materiałowego oraz stacje bunkrowe, które usytuowano także we Wrocławiu i Cigacicach ${ }^{42}$.

\section{Kadry}

Poważnym wyzwaniem przed uruchomieniem czechosłowackiej żeglugi na Odrze, stało się pozyskanie odpowiednich kadr, do pracy na lądzie i, przede wszystkim, na wodzie. W końcu marca 1948 roku polskie władze otrzymały od obcego armatora pierwszy wykaz osób do obsługi taboru odrzańskiego - ujmował on 71 Czechów i Słowaków a także 12 Niemców. Wśród załóg legitymujących się obywatelstwem czechosłowackim było 4 kapitanów holowników, 6 sterników, 41 bosmanów, 16 marynarzy, 3 maszynistów i pomocnik maszynisty. Najmłodszymi osobami w tej grupie byli, co zrozumiałe, marynarze, zaś najstarszymi najbardziej doświadczeni kapitanowie, sternicy, i mechanicy (maszyniści). Załogi niemieckie reprezentował wówczas kapitan, 8 sterników (urodzonych w latach 1886-1906), bosman oraz 2 mechaników ${ }^{43}$.

Zestawienie nie uwzględniało polskiego personelu, który w znacznej liczbie zasilił już w pierwszych miesiącach czechosłowackie jednostki pływające na Odrze. Byli to przede wszystkim sternicy i marynarze z długoletnią praktyką, autochtoni z przejętych przez Polskę terenów Opolszczyzny i Dolnego Śląska. Pełne zestawienie kadr czechosłowackiego przewoźnika śródlądowego w Polsce (Ostrawa zestawiała razem swój personel oraz spółki z o.o. we Wrocławiu) na koniec pierwszego roku funkcjonowania przedstawiono w tabeli 1 .

Armator czechosłowacki (a ściślej Ostrawa i Wrocław razem wzięte) zatrudniał w końcu 1948 roku 333 osoby, z tego na lądzie 43, w załogach pływających - 165, a pozostałych 125 zaangażowano w stoczni w Ratowicach. Byli to pracownicy trzech narodowości - rodzimy personel to $1 / 3$ załogi (102 Czechów bądź Słowaków - 30,63\%), prawie 2/3 stanowili Polacy (216 osób - 64,87\%), natomiast mniej niż 1/20 - Niemcy (15 osób - 4,50\%), którzy obsadzili stanowiska tylko na wodzie. W ogólnej liczbie zatrudnionych, więcej było załóg na barkach i holownikach $-49,56 \%$, potem stoczniowych - 37,53\%, a na końcu lądowych (12,91\%). Zatrudnieni poza Polską, w Ostrawie i Pradze oraz w żegludze na

${ }^{42}$ Tamże, ÚPV-T, k. 1286: „Zprava o výsledku reviše československé plavby na Odře” -30.07.1955; AP Wrocław, ZŻŚS, sygn. 2/529, s. 129-133.

${ }^{43}$ AAN Warszawa, MZO, sygn. 347, s. 23-29. 
Łabie, stanowili 13,51\% (45 osób), natomiast na terenie Polski oraz bezpośrednio w żegludze odrzańskiej - 86,49\% (288 osób) ${ }^{44}$.

Tabela 1. Personel Czechosłowackiej Żeglugi na Odrze (stan na koniec 1948 r.)

\begin{tabular}{|c|c|c|c|c|}
\hline Wyszczególnienie & $\begin{array}{c}\text { Czesi } \\
\text { i Słowacy }\end{array}$ & Polacy & Niemcy & Razem \\
\hline \multicolumn{5}{|c|}{ Zatrudnieni na lądzie } \\
\hline Ostrawa & 16 & - & - & 16 \\
\hline Praga & 4 & - & - & 4 \\
\hline Koźle & 3 & 1 & - & 4 \\
\hline Wrocław & 7 & 3 & - & 10 \\
\hline Krosno Odrzańskie & - & 1 & - & 1 \\
\hline Gryfino & - & 1 & - & 1 \\
\hline Szczecin & 4 & 3 & - & 7 \\
\hline Ogółem & 34 & 9 & - & 43 \\
\hline \multicolumn{5}{|c|}{ Załogi jednostek pływających } \\
\hline Na Łabie & 21 & - & 4 & 25 \\
\hline Na Odrze & 46 & 83 & 11 & 140 \\
\hline Ogółem & 67 & 83 & 15 & 165 \\
\hline \multicolumn{5}{|c|}{ Zatrudnieni w stoczni w Ratowicach } \\
\hline Pracownicy administracji & 1 & 12 & - & 13 \\
\hline Majstrowie & - & 7 & - & 7 \\
\hline Robotnicy & - & 105 & - & 105 \\
\hline Ogółem & 1 & 124 & - & 125 \\
\hline RAZEM A+B+C & 102 & 216 & 15 & 333 \\
\hline
\end{tabular}

Źródło: NA Praha, ÚPV-B, k. 958: odpis bezúročných státních zápůjček u národních dopravních podniků ČSPLO, ČSPO a ČSPD.

Wśród załóg na jednostkach pływających, podstawowych dla prowadzenia żeglugi, Polacy przeważali, zwłaszcza w grupie sterników i marynarzy oraz palaczy; Czesi i Słowacy zajęli przede wszystkim stanowiska kapitanów, chłopców okrętowych oraz mechaników wraz z ich pomocnikami; natomiast wśród kilkunastu zatrudnionych Niemców najliczniejsi byli sternicy ${ }^{45}$, co zaprezentowano w tabeli 2.

${ }^{44}$ NA Praha, ÚPV-B, kr. 958: odpis bezúročných státních zápůjček u národních dopravních podniků ČSPLO, ČSPO a ČSPD.

${ }^{45}$ Tamże. 
Tabela 2. Struktura personelu pływającego czechosłowackiego armatora na Odrze (stan na 31.12.1948)

\begin{tabular}{|l|c|c|c|c|}
\hline \multicolumn{1}{|c|}{ Wyszczególnienie } & $\begin{array}{c}\text { Czesi } \\
\text { i Słowacy }\end{array}$ & Polacy & Niemcy & Razem \\
\hline Kapitanowie & 4 & 3 & 2 & 9 \\
\hline Sternicy & 6 & 21 & 11 & 38 \\
\hline Marynarze oraz ich pomocnicy & 36 & 39 & 1 & 76 \\
\hline Chłopcy okrętowi & 9 & 5 & - & 14 \\
\hline Mechanicy (maszyniści) & 6 & 4 & 1 & 11 \\
\hline Pomocnicy maszynistów & 3 & - & - & 3 \\
\hline Palacze & 3 & 11 & - & 14 \\
\hline Ogółem & 67 & 83 & 15 & 165 \\
\hline
\end{tabular}

Źródło: NA Praha, ÚPV-B, k. 958: odpis bezúročných státních zápůjček u národních dopravních podniků ČSPLO, ČSPO a ČSPD.

Kadry zatrudnione na lądzie (pomijając stocznię w Ratowicach), zdominowane przede wszystkim przez pracowników administracji (43 osoby), to głównie Czesi lub Słowacy (79\%), następnie Polacy (21\%), nie było wśród nich Niemców. Niemal połowa personelu administracyjnego (20 osób) pracowała w Ostrawie i jej przedstawicielstwie w Pradze, w Polsce natomiast w tej grupie najsilniej obsadzona była spółka we Wrocławiu (10) oraz agencje w Szczecinie (7) i Koźlu (4), po jednej osobie zatrudniały placówki w Krośnie Odrzańskim i Gryfinie ${ }^{46}$.

We wstępnym okresie, trwającym właściwie kilka miesięcy, kiedy czechosłowacki tabor wprowadzano z Łaby na Odrę, obcy personel żeglugowy legitymował się jedynie tzw. imiennymi rozkazami pływania. Podpisane 12 stycznia 1949 roku „Porozumienie w sprawie odprawy, kontroli celnej oraz dokumentów dla załóg statków żeglugi śródlądowej” regulowało tę kwestię w ten sposób, że zatrudnieni na jednostkach musieli mieć książeczką żeglarską, której ważność przedłużało, na kolejne sezony nawigacyjne, polskie Ministerstwo Komunikacji, a następnie (od 1951 r.) - Ministerstwo Żeglugi ${ }^{47}$.

Problemem drażliwym, między stronami polską i czechosłowacką, było zatrudnienie Niemców przez zagranicznego armatora, konieczność ich wykorzystania argumentował szczupłością swoich kwalifikowanych kadr i potrzebą utrzymywania bez przerw eksploatacji. Warszawa sprzeciwiała się pracy wszelkich

\footnotetext{
46 Tamże.

${ }^{47}$ AMZV Praha, ZÚ Varšava 1945-1955, kr. 123, nota MSZ PRL do Amb. ČSR w Warszawie z 20.02.1954.
} 
załóg niemieckich, oferując - nazbyt optymistycznie w obliczu ogólnego deficytu personelu żeglugowego - gotowość zastąpienia ich w miarę możności Polakami. Po powstaniu Niemieckiej Republiki Demokratycznej, rząd w Pradze podjął akcję dyplomatyczną, by angażować do pracy obywateli tego państwa. Chodziło o umożliwienie im wstępu na polskie wody do Szczecina i z powrotem na podstawie dokumentów wystawianych dla żeglugi czechosłowackiej na Łabie (właściwie tylko legitymacji przedsiębiorstwa). Ze względu bowiem na niemieckie obywatelstwo załóg pływających, Czechosłowacy nie mogli uzyskać dla nich książeczek żeglarskich. Zawarcie w 1952 roku umowy o żegludze między Polską a NRD, jak również fuzja ČSPL i ČPO oraz odpływ taboru z Odry na Łabę, spowodowały, że na odrzańskiej drodze wodnej przestali pracować dla obcego armatora ostatni fachowcy z nowych Niemiec (zob. tab. 3$)^{48}$.

Oceny czechosłowackich kadr w żegludze odrzańskiej, dokonywane w okresie stalinowskim przez władze ministerialne tego kraju oraz placówki konsularne ČSR w Polsce, były skażone ideologicznym piętnem. Z tego punktu widzenia podkreślano niski poziom załóg barek i holowników, które zdaniem opiniujących były „pozostałością burżuazyjnego rządu i jego wychowania”. Sytuację taką uzasadniano tym, że personel jednostek pływających stanowił zamkniętą całość, oderwaną od życia politycznego, ponadto egzystował na obcej ziemi, gdzie nie funkcjonowały jeszcze czechosłowackie partyjne i związkowe organizacje ${ }^{49}$.

Politycznego wydźwięku nabierały szczególnie ucieczki za granicę, wprawdzie sporadyczne, załóg barek i holowników. Przedostanie się marynarza czechosłowackiego w czerwcu 1951 roku do Berlina Zachodniego wywołało reakcję zainteresowanych władz w Pradze, które postanowiły bliżej przyjrzeć się życiu tej grupy zawodowej. Miał temu służyć nie tylko „właściwszy” nabór do pływania na „niebezpiecznych” trasach, ale wysłanie do szczecińskiej agencji ČSPO instruktora partyjnego „który by dał gwarancję umocnienia politycznego i prac związkowych, gdyż Szczecin jest punktem stycznym marynarzy z Koźla oraz

${ }^{48}$ AAN Warszawa, MHZ, sygn. 92/27: prot. z zebrania przewod. pol. Sekcji Polskiej Kom. Komunik. Pol.-Czech. z 21.04.1949 r.; AMSZ Warszawa, z. 7, w. 42, t. 406, s. 147, 149: notatka Ratuszniakowa-Krabec z 30.11.1949, not. Kożusznik-Krabec z 12.12.1949; t. 407, s. 22, 35 : not. Ratuszniakowa-Krabec z 3.02.1950, not. Ratuszniakowa-Sedivy z 25.02.1950; t. 408, s. 5, s. 30, s. 131: not. Paduchowa-Biechal z 22.01.1951, not. Janicka-Biehal z 8.05.1951, not. z wizyty Piška u Wiernej z 3.12.1951; t. 409, s. 75: not. Jankowski-Zimak z 30.05.1952; NA Praha, MD I, kr. 823: pismo MŻ PRL z 19.02.1952 do MD w Pradze; APS, SUM, sygn. I/308, s. 119: prot. z narady 27.11.1952.

${ }^{49}$ AMZV Praga, TO, k. 3: pismo MD z 19.05.1951 do MZV; „Pro domo” - Exp.I č.121870/51 A-II/1 z 19.05.1951. 
wełtawskiej i łabskiej drogi wodnej”50. Naciski placówek konsularnych przyniosły ten skutek, że przed połową lat pięćdziesiątych działały już przy dyrekcji ČSPO w Koźlu czechosłowacka i polska rada zakładowa oraz podstawowe organizacje partyjne KSČ i PZPR, organizujące indoktrynujące szkolenia polityczne załóg, a także klub, dysponujący kilkoma kołami zainteresowań. Dowodem dobrej współpracy w zakresie kultury było założenie tutaj polsko-czechosłowackiego zespołu pieśni i tańca, składającego się z pracowników obu armatorów na Odrze (ŻnO i ČSPO), propagującego w najbliższej okolicy czechosłowacką muzykę i kulturę ${ }^{51}$.

$\mathrm{Na}$ początku lat pięćdziesiątych, dyscyplinę pracy Polaków, zatrudnionych w ČSPO, z reguły oceniano negatywnie, wiążąc to z ich znacznie niższymi poborami w stosunku do poziomu płac polskiego armatora na Odrze, który wprowadził żeglugę nocną. Pojawiał się także argument polityczny, ponieważ wskazywano na podatność niektórych załóg polskich, złożonych z tzw. ślązaków, na „adenauerowską propagandę"52. Próbą poprawy sytuacji miał być wprowadzony w połowie 1954 roku przez obcą żeglugę bodźcowy system płac, bazujący na wielkości tonokilometrów. Ograniczanie eksploatacji wobec niedostatku towarów i niskich stanów wody oraz związany z tym niewielki ruch jednostek czy znaczne ich przestoje w portach, nie przyniosły jednak wzrostu zarobków. Ich wysokość była wtedy niemal dwukrotnie niższa niż wynagrodzenia załóg polskiego przewoźnika po Odrze. W następstwie tego znacznie obniżyło się zdyscyplinowanie pracowników, a zarazem zwiększyła fluktuacja. W ciągu kilku miesięcy 1954 roku opuściło ČSPO 45 polskich marynarzy, którzy szukali lepszego zarobku,

\footnotetext{
${ }^{50}$ Tamże, pisma kon. gen. ČSR w Szczecinie z 12 i 14.06. oraz 12.11.1951 do MZV w Pradze i Amb. ČSR w Warszawie; tamże, kr. 4: pismo kon. gen. ČSR w Szczecinie z 5.06.1950 do MZV w Pradze i Amb. ČSR w Warszawie; tamże, ZÚ Varšava 1945-1955, kr. 91: pismo kon. gen. ČSR w Szczecinie z 21.02.1950 do MZV i Amb. ČSR w Warszawie.

${ }^{51}$ AMZV Praha, ZÚ Varšava 1945-1955, kr. 91: pisma gen. kon. ČSR w Szczecinie z 13.11.1952 do Amb. ČSR w Warszawie oraz do Czechosłowackiej Żeglugi Łabsko-Odrzańskiej zakład Odra w Koźlu, pismo gen. kon. ČSR w Szczecinie z 20.12.1952 do MZV i Amb. ČSR w Warszawie, pismo gen. kon. ČSR w Szczecinie z 4.09.1954 do MZV i Amb. ČRS w Warszawie; tamże, TO, kr. 4: inf. kon. ČSR w Katowicach z 25.09.1954 dla Amb. ČSR i MZV, pismo gen. kon. ČSR w Szczecinie z 4.09.1954.

${ }^{52}$ AMZV Praga, TO, k. 4: pismo gen kon. ČSR w Szczecinie z 18.07.1952 do MZV i Amb. ČSR w Warszawie.
} 
a to z kolei pociągnęło za sobą przerzucenie kolejnych kilkunastu jednostek pływających z Odry na Łabę 53 .

Zrozumiałe, że stopniowe przechodzenie taboru na niemiecką rzekę skutkowało zmniejszaniem się liczby personelu zatrudnianego na Odrze, który w 1952 roku stanowił już tylko nieco ponad 61\% w stosunku do stanu w roku ubiegłym. Dotyczyło to zarówno osób pracujących „na lądzie”, jak i „na wodzie”, co przedstawiono w tabeli 3 .

Tabela 3. Liczba pracowników Czechosłowackiej Żeglugi na Odrze w latach 1948-1955 (stan na koniec roku)

\begin{tabular}{|l|c|c|c|c|c|c|c|c|c|c|}
\hline \multirow{2}{*}{ Rok } & \multicolumn{3}{|c|}{ Lądowi } & \multicolumn{3}{|c|}{ Pływający } & \multicolumn{3}{|c|}{ Razem } & Ogółem \\
\cline { 2 - 12 } & Czesi & Polacy & Niemcy & Czesi & Polacy & Niemcy & Czesi & Polacy & Niemcy & \\
\hline 1948 & 35 & 133 & - & 67 & 83 & 15 & 102 & 216 & 15 & 333 \\
\hline 1949 & 50 & 81 & - & 96 & 127 & 8 & 146 & 208 & 8 & 362 \\
\hline 1950 & 80 & 86 & - & 112 & 204 & 12 & 192 & 290 & 12 & 494 \\
\hline 1951 & 90 & 109 & - & 140 & 283 & 9 & 230 & 392 & 9 & 631 \\
\hline 1952 & 37 & 57 & - & 22 & 272 & - & 59 & 329 & - & 388 \\
\hline 1953 & 42 & 56 & - & 31 & 241 & - & 73 & 297 & - & 370 \\
\hline 1954 & 35 & 47 & - & 51 & 191 & - & 86 & 238 & - & 324 \\
\hline $195 *^{*}$ & 34 & 33 & - & 20 & 144 & - & 54 & 177 & - & 231 \\
\hline
\end{tabular}

*Dane polskie.

Źródło: NA Praha, MD II, kr. 685: „Zpráva o československé plavbě na Odře” - 05.955; AAN, MŻiGW, sygn. 16/6: Analiza dotychczasowego wykonania postanowień umowy zawartej między Żegluga na Odrze a ČSPLO w sprawie żeglugi śródlądowej na wodach obu państw w 1956 r. -24.09 .1956$.

W maju 1955 roku ČSPO zatrudniała na terytorium Polski 46 osób w administracji (umysłowych), z czego 31 Czechosłowaków i 15 Polaków oraz 26 polskich robotników (prac. fizycznych). Rozmieszczenie tych sił było następujące: w centrali w Koźlu pracowały 54 osoby (35 umysłowych i 19 robotników warsztatowych), w Szczecinie - 15 (8 prac. administracyjnych i 7 robotników), dwóch pracowników umysłowych we Wrocławiu, a jeden w Widuchowej. Z kolei na

${ }^{53}$ Tamże: inf. kon. ČSR w Katowicach z 25.09.1954 dla Amb. ČSR w Warszawie i MZV TO, pismo gen. kons. ČSR w Szczecinie z 1.06.1953 do MZV i Amb. ČSR w Warszawie; tamże, ZÚ Varšava 1945-1955, kr. 91: pismo gen. kon. ČSR w Szczecinie z 4.09.1954 do MZV i Amb. ČSR w Warszawie; AP Wrocław, PŻnO-DW, sygn. 2/41, s. 148: Notatka z narady roboczej 11.05 .1955 we Wrocławiu. 
koniec tego roku, gdy całkowita obsada obcej spółki sięgała 231 osób, pracownicy na lądzie (umysłowi i fizyczni) liczyli w sumie 67 osób, niemal po połowie Czechów i Słowaków oraz Polaków (33) - przede wszystkim robotników warsztatowych. Personel żeglugowy obejmował 164 osoby, w zdecydowanej przewadze liczebnej polskiej narodowości (144), które właściwie miały podstawowy wpływ na rezultaty eksploatacyjne przedsiębiorstwa ${ }^{54}$.

\section{Bibliografia}

Źródła archiwalne

Archiwum Akt Nowych w Warszawie:

Biuro Prezydialne Krajowej Rady Narodowej, sygn. 69.

Centralny Urząd Planowania, sygn. 1871, 92/27.

Ministerstwo Komunikacji, sygn. 954, 955, 956.

Ministerstwo Handlu Zagranicznego, sygn. 92/27.

Ministerstwo Przemysłu i Handlu, sygn. 3563.

Ministerstwo Skarbu, sygn. 679.

Ministerstwo Ziem Odzyskanych, sygn. 1385a.

Ministerstwo Żeglugi, sygn. 121.

Ministerstwo Żeglugi i Gospodarki Wodnej, sygn. 16/6.

Urząd Rady Ministrów, sygn. 2/332, 219/23.

Archiv Ministerstva zahraničních věcí Praha:

Zaztupitelsky Úřad Varšava 1945-1955, kr. 91, 110, 123, 128.

TO, k. 3, 4.

Archiwum Ministerstwa Spraw Zagranicznych w Warszawie:

Zespół 7, wiązka 42, t. 406, 407, 408.

Zespół 28, wiązka 13, t. 80.

Archiwum Państwowe w Szczecinie:

Państwowa Żegluga na Odrze, sygn. 38.

Szczeciński Urząd Morski, sygn. I/100, I/308.

Archiwum Państwowe we Wrocławiu:

Państwowa Żegluga na Odrze - Dyrekcja we Wrocławiu, sygn. 2/41.

Zjednoczenie Żeglugi Śródlądowej we Wrocławiu, sygn. 2/529.

\footnotetext{
${ }^{54}$ NA Praha, MD II, kr. 685: „Zpráva o československé plavbě na Odře” - 05.1955; AAN Warszawa, Ministerstwo Żeglugi i Gospodarki Wodnej (dalej MŻiGW), sygn. 16/6: Analiza dotychczasowego wykonania postanowień umowy zawartej między Żeglugą na Odrze a ČSPLO w sprawie żeglugi śródlądowej na wodach obu państw w 1956 r. - 24.09.1956.
} 
Národní archiv Česke republiky Praha:

Ministerstvo Dopravy I, karton 225, 298, 810, 821, 823.

Ministerstvo Dopravy II, karton 685.

Úřad předsednictva vlády - běžná spisovna, karton 958, 1142.

Úřad předsednictva vlády - tajná spisovna, karton 1286.

\section{Literatura}

Beister K., Geneza czechosłowackiej strefy wolnocłowej w Szczecinie, „Przegląd Komunikacyjny" 1949, nr 6.

Bissaga T., Komunikacje w konwencji polsko-czechosłowackiej, „Życie Gospodarcze” 1948, nr 6.

Dopierała B., Powiazania Szczecina z Czechosłowacją w dwudziestoleciu międzywojennym, „Przegląd Zachodni” 1961, nr 2.

Dopierała B., Zarys dziejów Odry, w: Odra i Nadodrze, Warszawa 1976.

Hutnikiewicz A., Szczecin w polskiej polityce morskiej w latach 1945-1950, Szczecin 1991.

Hutnikiewicz A., Szczecin w stosunkach polsko-czechosłowackich 1945-1950, w: Historia luxveritatis. Ksiega pamiatkowa dedykowana profesorowi Zdzisławowi Chmielewskiemu z okazji 60 rocznicy urodzin, Szczecin 2002.

Kamiński M.K., Polsko-czechosłowackie stosunki polityczne 1945-1948, Warszawa 1990.

Kořalková K., Československo-polské vztahy 1945-1961, Praha 1962.

Kulíková L., Československo-polské hospodářské styky předuzavřením spojenecké smlouvy (květen 1945-březen 1947), „Slovanské Historické Studie” 1992, t. XVIII.

Marczak T., Granica zachodnia w polskiej polityce zagranicznej w latach 1944-1950, Wrocław 1995.

Opoka Z., Stosunki polsko-czechostowackie w latach 1944-1948, „Zeszyty Naukowe Wojskowej Akademii Politycznej" 1973, nr 75.

„Sbírka zákonů republiky Československe” 1952, nr 25.

Skodlarski J., Rokowania gospodarcze polsko-czechosłowackie w 1947 r., „Acta Oeconomica Pragensia" 2007, nr 7.

Skodlarski J., Procesy integracyjne w polsko-czechosłowackich stosunkach gospodarczych (1947-1949), „Acta Universitatis Lodziensis”, Nauki Ekonomiczne i Socjologiczne 1979, seria III, nr 39.

Slovník veřejného pravá československého, t. 2, red. J. Havelka, Brno 1932.

Švarc B., Czechosłowacka żegluga śródlądowa na obszarze Europy Środkowej, „Technika i Gospodarka Morska” 1974, nr 12.

Techman R., Szczecin w aktach polskiej stużby dyplomatycznej 1945-1950, w: 50 lat Polski na Pomorzu Zachodnim. Polityka - Społeczeństwo - Kultura. Materiały z sesji naukowej (19-20 maja 1995), red. K. Kozłowski, E. Włodarczyk, Szczecin 1996. 
Szczepańska A., Rejon czechosłowacki w porcie szczecińskim w latach 1949-1956, „Przegląd Zachodniopomorski” 2006, nr 3.

Zawadka M., Społeczne i gospodarcze aspekty wykorzystania Odry po II wojnie światowej, 1999 - pr. dokt., mps, Bibl. Uniw. Zielonog.

Zintel J., Układ komunikacyjny polsko-czechosłowacki, „Gospodarka Morska” 1948, nr 1.

\begin{abstract}
Abstrakt
Artykuł dotyczy żeglugi na Odrze, która po II wojnie światowej była ważnym szlakiem dla czechosłowackiego handlu. Zaprezentowano w nim negocjacje handlowe pomiędzy rządami polskim i czechosłowackim zakończone podpisaniem traktatu o transporcie. Zgodnie z jego postanowieniami we Wrocławiu powstała spółka zajmująca się transportem towarów, zarządzaniem stocznią. W tekście omówiono również pozycję, jaką zajmowała na polskim rynku, strukturę organizacyjną oraz skład osobowy.
\end{abstract}

\title{
The Czechoslovak Navigation on the Oder River In the Years 1947-1957. Part 1
}

\begin{abstract}
After the Second World War the Czechoslovak Government attached importance to the navigation on the Oder River, which - in addition to the Elbe and the Danube - was to be an important route for international trade of the country. The trade negotiations with Poland, which had the whole navigable length of the river, were crowned with signing the Transportation Treaty on July $1^{\text {st }}$. It vested the Republic of Czechoslovakia with special powers in the Szczecin Harbour (free of duty zone) and a privileged position in the river and sea navigation. Following the stipulations of the Transportation Treaty there was another contract signed on May 12 ${ }^{\text {th }}, 1948$ in Wrocław, an agreement to create a limited liability company, the Czechoslovak Oder Navigation Company (CSPO), which dealt with freight transport of merchandise goods on the Oder and its tributaries, as well as on the (German) canals connected to it; the Company also managed a shipyard and auxiliary workshops to repair its own shipping. The article presents the creation of the CSPO, its position in the Polish legal system, its inner structure, size and staff, organisational changes, rules of cooperation with the Polish Oder carrier, i.e. the legal, organisational and personnel conditions of the functioning of a foreign ship owner, against the background of developing the transport function of the Oder in the Polish-Czechoslovak relations.
\end{abstract}

